\title{
EFFECT OF BODY MASS INDEX (BMI) ON MORTALITY AND READMISSION OF HEART FAILURE PATIENTS IN CARDIOVASCULAR OUTPATIENT CARE UNIT AT DR. SOETOMO HOSPITAL, SURABAYA
}

\author{
Sella Rizkita Lestari ${ }^{1}$, Andrianto ${ }^{2}$, J. Nugroho ${ }^{2}$ \\ ${ }^{1}$ Medical Doctor Program, Faculty of Medicine, Universitas Airlangga \\ ${ }^{2}$ Department of Cardiology and Vascular Medicine, Faculty of Medicine, Universitas Airlangga
}

\begin{abstract}
ABSTRAK
Obesitas merupakan salah satu faktor risiko gagal jantung, baik bagi pria maupun wanita. Namun, studi terbaru melaporkan bahwa pasien gagal jantung dengan indeks massa tubuh yang tinggi mempunyai prognosis yang lebih baik. Studi ini dilakukan untuk membuktikan pengaruh indeks massa tubuh terhadap kejadian kematian dan rehospitalisasi pasien gagal jantung di Poliklinik Jantung RSUD Dr. Soetomo. Penelitian ini merupakan penelitian analitik observasional. Subjek penelitian terdiri dari pasien penyakit jantung di Poliklinik Jantung RSUD Dr. Soetomo yang memenuhi kriteria inklusi dan eksklusi. Dengan teknik purposive sampling, didapatkan 59 pasien gagal jantung di poliklinik jantung sebagai subjek penelitian. Indeks massa tubuh subjek penelitian dihitung dengan mengukur secara langsung berat dan tinggi badan pasien pada Februari-Maret 2014. Berdasarkan indeks massa tubuhnya, subjek penelitian kemudian dibagi menjadi dua kategori, yaitu IMT normal dan meningkat. Data kejadian kematian dan rehospitalisasi dikumpulkan pada Oktober 2014. Data-data yang ada kemudian diuji dengan Fisher Exact Test. Setelah 8 bulan, didapatkan 5 pasien (8,5\%) meninggal karena faktor kardiovaskular dan 7 pasien (11,9\%) masuk rumah sakit kembali. Di antara 28 pasien dengan IMT normal, 3 (10,7\%) meninggal dan 3 (10,7\%) masuk rumah sakit kembali. Di antara 31 pasien dengan IMT meningkat, 2 (6,5\%) meninggal dan 4 (12,9\%) masuk rumah sakit kembali. Dengan uji Fisher Exact Test, diperoleh nilai p 0,661 yang menunjukkan bahwa indeks massa tubuh tidak berpengaruh terhadap kejadian kematian. Dengan uji tersebut juga, diperoleh nilai p 1,000 yang menunjukkan bahwa indeks massa tubuh tidak berpengaruh terhadap kejadian rehospitalisasi. (FMI 2016;52:4750)
\end{abstract}

Kata kunci: indeks massa tubuh, gagal jantung, kematian, rehospitalisasi, rawat jalan

\begin{abstract}
Obesity is one of risk factors for heart failure in both men and women. Paradoxically, recent studies have shown that high BMIs in heart failure patients were asssociated with better outcomes. This study was aimed to prove the effect of body mass index on mortality and readmission in heart failure patients in cardiovascular outpatient care unit at Dr. Soetomo Surabaya Hospital. The research design was observational analytical study. Subjects consisted of all patients with heart disease in cardiovascular outpatient care unit at Dr. Soetomo Surabaya Hospital that meet the inclusion and exclusion criteria. Through the purposive sampling, 59 patients diagnosed with heart failure were selected. Direct measurements of body weight and height were conducted in February through March 2014 to calculate the BMIs. Based on their BMIs, subjects were then placed into two categories, which were patients with normal and elevated BMIs. Information on deaths and readmissions were gathered in October 2014. The relationship between two variables were then analyzed using Fisher Exact Test. After 8 months of follow up, 5 people (8.5\%) died of cardiovascular cause and 7 (11.9\%) were re-admitted to the hospital. Among 28 patients with normal BMIs, 3 (10.7\%) died and 3 (10.7\%) were readmitted. Among 31 patients with elevated BMIs, 2 (6.5\%) died and 4 (12.9\%) were re-admitted to the hospital. By using Fisher Exact Test, it was shown that there is no effect of BMI on mortality $(p=0.661)$ and readmission $(p=1.000)$ in heart failure patients. (FMI 2016;52:47-50)
\end{abstract}

Keywords: body mass index, heart failure, mortality, readmission, outpatient

Correspondence: Sella Rizkita Lestari. Medical Doctor Program, Faculty of Medicine, Universitas Airlangga phone: 08113050081.e-mail: sella.rizkita@gmail.com

\section{INTRODUCTION}

Heart failure is an expanding problem throughout the world as more than 20 million people all around the world suffer from it (Joseph et al 2009). As many as 1.4 million new cases of congestive heart failure (due to rheumatic heart disease, hypertensive heart disease, ischaemic heart disease, or inflammatory heart disease) were reported in Southeast Asia in 2004. The incidence of heart failure in Southeast Asia was higher than in 5 other regions: 0.5 million new cases in Africa, 0.8 million new cases in America, 0.4 million in Eastern Mediterranean, 1.3 million in Europe, and 1.3 million in Western Pacific (WHO 2008). Obesity is one of 
important risk factors for heart failure in both men and women (Kenchaiah et al 2002). However, a cohort study of outpatient diagnosed with heart failure reported that higher BMIs were associated with lower mortality risks. Overweight and obese patients in the study had lower mortality risks than patients with healthy weight (Curtis et al 2005).

Another study reported that in patients who had symptomatic heart failure and either reduced or preserved left ventricular systolic function, underweight or low BMIs were associated with increased mortality, mainly in the patients without any edema (Kenchaiah et al 2007). This phenomenon however still cannot be explained clearly and may be related to the age in which the obese patients were first diagnosed with heart failure, the highly catabolic nature of the heart failure disease, and other factors (Bui et al 2011). This study was aimed to prove the effect of body mass index on mortality and readmission in heart failure patients. The result of this study was intended to provide more informations about the phenomenon and be used as a reference for the development of cardiology, especially in dealing with heart failure managements.

\section{MATERIALS ANND METHODS}

The research design was observational analytical study. Subjects were selected from heart failure patients in cardiovascular outpatient care unit at Dr. Soetomo Surabaya Hospital during the month of February and March 2014 by using a purposive sampling method. The patients who did not have any contact numbers and whose body weight and height could not be measured were not included in this study. Underweight patients whose BMIs were less than $18.5 \mathrm{~kg} / \mathrm{m} 2$ were also excluded.

Direct measurements of body weight and height to calculate the BMIs were conducted to heart failure patients visiting cardiovascular outpatient care unit at Dr. Soetomo Surabaya Hospital in February through March 2014. Based on the BMIs, subjects were then divided into two categories, which were patients with normal and elevated BMIs. Patients with normal BMIs were those of which BMIs ranged from 18.5-24.99 $\mathrm{kg} / \mathrm{m} 2$. Patients with elevated BMIs were those of which BMIs were $25 \mathrm{~kg} / \mathrm{m} 2$ or higher. Aside from the BMIs, other demographic and clinical characteristics, such as age, sex, NYHA classifications, heart failure etiology, history of diabetes, and treatments, were also collected. Interviews were done to gain informations on the history of diabetes and NYHA classifications. Age, sex, heart failure etiology, medical treatments used by the patients were collected from medical records.
Information on deaths and readmissions were gathered from the patients or their families through contacting their numbers or visiting them after 8 months of follow up. Those informations on deaths and readmissions were distributed based on the BMIs and possible confounding factors, such as age, sex, history of ischaemic heart disease or diabetes, NYHA classifications, and medical treatments. Two main variables were then analyzed to know the effect of BMIs on mortality and readmission in heart failure patients with the confounding factors being ignored.

\section{RESULTS}

By using the purposive sampling technique, 59 subjects aged between $37-81$ years with an average age of 57.83 years and a standard deviation of 9.736 were obtained. Most heart failure patients in this study were between 59-66 years old. As many as 18 (30.5\%) of 59 patients were aged between those years. Female patients were slightly more than the male. A total of 31 $(52.5 \%)$ patients were female and 28 (47.5\%) were male. There were only 37 of 59 subjects of which the heart failure etiology could be collected. Most of the 37 patients had either history of ischaemic heart disease or hypertension. Cardiomyopathy was the least common heart failure etiology the subjects had. Most of 59 heart failure patients were placed in Class II based on the NYHA Functional Classification. A total of 39 (66.1\%) patients were classified function capacity II. It was because this study was conducted on outpatients that the number of subjects with function capacity III was very few and there were no subjects with function capacity IV. History of diabetes was not common in the subjects. There were only $18(30.5 \%)$ of 59 patients who had history of diabetes. Prescription of diuretics, such as furosemide and hydrochlorothiazide, was the most prevalent among heart failure patients in this study. A total of 54 patients used diuretics.

Subjects had an average BMI of 26.1145 and a standard deviation of 4.71274 . Most $(52.5 \%)$ of the patients had elevated BMIs. After 8 months of follow-up, 5 (8.5\%) patients died of cardiovascular cause. Most of them were male and aged between 59-66 years. One of them had a history of ischaemic heart disease. One had a history of cardiomyopathy. There were more (3 patients) patients who died were in Class II than in any other classes. However, Class III had the largest percentage of mortality events. Twenty percent of patients in Class III died. Two (11.1\%) of 18 patients with history of diabetes died, while there were only 3 $(7.3 \%)$ of 41 patients with no history of diabetes who died. 
Table 1 shows that mortality was more common in patients with normal BMIs than in patients with elevated BMIs. Three (10.7\%) of 28 patients with normal BMIs died of cardiovascular cause. There were only $2(6.5 \%)$ of 31 patients with elevated BMIs who died.

Table 1. Mortality in heart failure patients in the cardiovascular care unit at Dr. Soetomo Surabaya Hospital defined by the BMIs.

\begin{tabular}{lccccccc}
\hline & & \multicolumn{9}{c}{ Died } & \multirow{2}{*}{ Total } & $\%$ \\
\cline { 3 - 6 } & & Yes & $\%$ & No & $\%$ & & \\
\hline \multirow{2}{*}{ BMI } & Normal & 3 & 10,7 & 25 & 89,3 & 28 & 100 \\
& Elevated & 2 & 6,5 & 29 & 93,5 & 31 & 100 \\
\hline Total & & 5 & 8,5 & 54 & 91,5 & 59 & 100 \\
\hline
\end{tabular}

In this study, readmissions in heart failure patients were more common than mortality events. A total of 7 $(11.9 \%)$ patients were readmitted to the hospital as inpatient during 8 months of study. Readmission was more common in the female patients and patients aged between 59-66 years. Based on the clinical characteristics, readmission was more prevalent in the patients with function capacity I and with history of diabetes. Thirty seven patients with heart failure etiology data, there were $5(13.5 \%)$ patients who were readmitted to the hospital due to cardiovascular reason. Ischaemic heart disease and hypertension were the most common in these 5 patients. Readmissions were more common in patients with elevated BMIs than in patients with normal BMIs. Of 7 patients who were readmitted to the hospital during 8 months of study, 4 were patients with elevated BMIs and 3 were patients with normal BMIs.

Table 2. Readmissions in heart failure patients in the cardiovascular care unit at Dr. Soetomo Surabaya Hospital defined by the BMIs.

\begin{tabular}{lcccccccc}
\hline & & \multicolumn{3}{c}{ Readmissions } & \multirow{2}{*}{ Total } & $\%$ \\
\cline { 3 - 6 } & & Yes & $\%$ & No & $\%$ & & \\
\hline \multirow{2}{*}{ BMI } & Normal & 3 & 10.7 & 25 & 89.3 & & 28 & 100 \\
& Elevated & 4 & 12.9 & 27 & 87.1 & 31 & 100 \\
\hline Total & & 7 & 11.9 & 52 & 88.1 & 59 & 100 \\
\hline
\end{tabular}

Table 2 shows that there were $4(12.9 \%)$ of 31 patients with elevated BMIs who were readmitted to the hospital. Among patients with normal BMIs, there were $3(10.7 \%)$ who were readmitted to the hospital.

\section{DISCUSSION}

Subjects in this study had an average age of 57.83 years. This is not much different from other study conducted on acute decompensated heart failure patients in Indonesia (Siswanto et al 2010). However, subjects in this study is younger compared to other studies in the Europe (Zamora et al 2007, Haass et al 2011). According to Callender et al (2014), the average age of patients in studies is largely correlated with country income level and the Human Development Index (HDI) of the country where the study took place $(\mathrm{r}=0.71, \mathrm{p}<$ $0.001)$. Based on this report, heart failure patients in Indonesia are more likely to be younger in age.

Male sex is one of risk factors for congestive heart failure (He et al 2001). However, female patients in this study were more in numbers than male patients. This discrepancy may occur because the sample size of this study was too small and the sampling technique were less able to represent the population. Most of the patients in this study had either history of ischaemic heart disease or hypertension. This is consistent with the study reported by Callender et al (2014) that in patients with heart failure, ischaemic heart disease was the main reported cause of heart failure in low and middle income countries, except Africa and the Americas, where hypertension was prevalent.

This study involved outpatients with heart failure and thus the majority $(66.1 \%)$ of the subjects had function capacity II. In Class II, the patients have symptomatic heart failure with slight limitation of physical activity. By using Fisher Exact Test, it was shown that there was no effect of BMI on mortality in heart failure outpatients $(p>0.05)$. This result is in contrast to several studies that reported the phenomenon of obesity paradox or reverse epidemiology, when heart failure patients with high BMIs appeared to have better prognosis. A cohort study involving 7677 heart failure outpatients reported that after a follow-up with an average of 37 months, overweight and obese patients had smaller risk of death compared to patients with normal weight (Curtis et al 2005). Other study of chronic heart failure patients reported the same phenolmenon (Oreopoulos et al 2008).

This phenomenon still cannot be explained clearly and may be related to the age in which the obese patients were first diagnosed with heart failure (Bui et al 2011). In addition, history of percutaneous coronary intervention which was common in obese patients (Fitzgibbons et al 2009) was also reported to affect the incidence of death in heart failure patients (Gruberg et al 2002). By using Fisher Exact Test, it was also shown that there is no effect of BMI on readmissions in heart failure outpatients $(p>0.05)$. This is in contrast to a study of heart failure patients with preserved ejection fraction. The study stated that there was an increased risk of 
hospitalization in heart failure patients whose BMIs were $35 \mathrm{~kg} / \mathrm{m} 2$ or more (Haass et al 2011).

However, other study reported that rates of all-cause hospitalization and hospitalization due to worsening heart failure were similar across BMI groups. Overweight and obese patients with heart failure may have less severe myocardial dysfunction than patients with healthy weight, yet be equally vulnerable to developing decompensated heart failure (Curtis et al 2005).

\section{CONCLUSION}

By using Fisher Exact Test, it was shown that there is no effect of BMI on mortality $(\mathrm{p}=0.661)$ and readmission $(\mathrm{p}=1.000)$ in heart failure patients in cardiovascular outpatient care unit at Dr. Soetomo Surabaya Hospital.

\section{REFERENCES}

Bui AL, Horwich TB, Fonarow GC (2011). Epidemiology and risk profile of heart failure. Nature Reviews Cardiology 8, 30-41

Callender T, Woodward M, Roth G, Farzadfar F, Lemarie JC, Gicquel S, Atherton J, Rahimzadeh S, Ghaziani M, Shaikh M, Bennett D, Patel A, Lam CSP, Sliwa K, Barretto A, Siswanto BB, Diaz A, Herpin D, Krum H, Eliasz T, Forbes A, Kiszely A, Khosla R, Petrinic T, Praveen D, Shrivastava R, Xin D, MacMahon S, McMurray J, Rahimi K (2014). Heart failure care in low-and middle-income countries: a systematic review and meta-analysis. PLoS Medicine 11, e1001699

Curtis JP, Selter JG, Wang Y, Rathore SS, Jovin IS, Jadbabaie F, Kosiborod M, Portnay EL, Sokol SI, Bader F, Krumholz HM (2005). The obesity paradox: body mass index and outcomes in patients with heart failure. Archives of Internal Medicine 165, 55-61

Fitzgibbons TP, Hardy OT, Lessard D, Gore JM, Yarzebski J, Goldberg RJ (2009). Body mass index, treatment practices, and mortality in patients with acute heart failure. Coronary Artery Disease 20, 536543
Gruberg L, Weissman NJ, Waksman R, Fuchs S, Deible R, Pinnow EE, Ahmed LM, Kent KM, Pichard AD, Suddath WO, Satler LF, Lindsay J Jr (2002). The impact of obesity on the short-term and long-term outcomes after percutaneous coronary intervention: the obesity paradox? J Am Colle Cardiol 39, 578-584

Haass M, Kitzman DW, Anand IS, Miller A, Zile MR, Massie BM, Carson PE (2011). Body mass index and adverse cardiovascular outcomes in heart failure patients with preserved ejection fraction: results from the Irbesartan in Heart Failure with Preserved Ejection Fraction (I-PRESERVE) trial. Circulation Heart Failure 4, 324-331

He J, Ogden LG, Bazzano LA, Vupputuri S, Loria C, Whelton PK (2001). Risk factors for congestive heart failure in US men and women: NHANES I epidemiologic follow-up study. Archives of Internal Medicine 161, 996-1002

Joseph SM, Cedars AM, Ewald GA, Geltman EM, Mann DL (2009). Acute decompensated heart failure: contemporary medical management. Texas Heart Institute Journal 36, 510-520

Kenchaiah S, Evans JC, Levy D, Wilson PWF, Benjamin EJ, Larson MG, Kannel WB, Vasan RS (2002). Obesity and the risk of heart failure. N Engl J Med 347, 305-313

Kenchaiah S, Pocock SJ, Wang D, Finn PV, Zornoff LA, Skali H, Pfeffer MA, Yusuf S, Swedberg K, Michelson EL, Granger CB, McMurray JJ, Solomon SD; CHARM Investigators (2007). Body mass index and prognosis in patients with chronic heart failure: insights from the Candesartan in Heart failure: Assessment of Reduction in Mortality and morbidity (CHARM) program. Circulation 116, 627-636

Oreopoulos A, Padwal R, Kalantar-Zadeh K, Fonarow GC, Norris CM, McAlister FA (2008). Body mass index and mortality in heart failure: a meta-analysis. Am Heart J 156, 13-22

Siswanto BB, Radi B, Kalim H, Santoso A, Suryawan R, Erwinanto, Antono E, Santoso T (2010). Heart failure in NCVC Jakarta and 5 hospitals in Indonesia. CVD Prevention and Control 5, 35-38

WHO (2008). The Global Burden of Disease 2004 Update. Geneva: WHO Press

Zamora E, Lupón J, Urrutia A, González B, Mas D, Pascual T, Domingo M, Valle V (2007). Does body mass index influence mortality in patients with heart failure? Rev Esp Cardiol 60, 1127-1134 